\title{
Defoliation Response of Bluebunch Wheatgrass and Crested Wheatgrass: Why We Cannot Graze These Two Species in the Same Manner
}

\author{
CINDY L. MEAYS, ANDREA S. LALIBERTE, AND PAUL S. DOESCHER
}

$\mathrm{H}$ ave you ever wondered why crested wheatgrass responds more favorably to defoliation than bluebunch wheatgrass? Or, why can crested wheatgrass be grazed heavily early in the season without decreasing its overall vigor and maintain itself on the land, whereas the same grazing prescription on bluebunch wheatgrass can be detrimental to the plant? In part, the answer lies in the evolutionary history of these two species. Crested wheatgrass and bluebunch wheatgrass have evolved in very different ecosystems under dissimilar grazing pressures, which has resulted in very different responses to herbivory.

These two species have similarities in the way they grow, but much different histories in North America. Crested wheatgrass is a persistent, drought and grazing tolerant, very vigorous cool season bunchgrass, introduced to more than 12 million acres in the United States and 20 thousand acres in Canada. It is a Eurasian species that probably evolved in its native environment under heavy grazing by large populations of ungulates. The first introduction of crested wheatgrass to North America was by N.E. Hansen of the South Dakota Agricultural Experiment Station in 1898. The seed was obtained from the Valuiki Experiment Station approximately 150 miles north of Volgograd, U.S.S.R. In 1906 more seed was brought from the U.S.S.R. experiment station and was planted and propagated at experiment stations in Newell, South Dakota, and Mandan, North Dakota. The first seed brought to Canada was acquired in 1915 from the United States Department of Agriculture, and was planted in experimental plots at the University of Saskatchewan. Seed was also obtained from Russian and Siberia.

Bluebunch wheatgrass is one of the most important perennial bunchgrasses native to the dry grassland and sagebrush steppe of the western US and Canada. It is generally found in semiarid grassland, sagebrush steppe, and further north in low elevation, dry open forests. It has a wide ecological amplitude, grows under a variety of moisture conditions, and provides forage for a variety of wildlife and livestock. Bluebunch wheatgrass is drought resistant and prefers well-drained loamy soils, and south facing slopes. Historically it was more dominant in the Intermountain grassland and sagebrush ecosystems, but its low resistance to early grazing and other disturbance factors enabled other competitive species such as cheatgrass and medusahead to invade some of these areas and decrease its abundance.

\section{Life Histories}

Crested wheatgrass reproduces both vegetatively through tillering and by seed. It produces large amounts of high-quality seed that can germinate, emerge, and grow under adverse conditions. Under favorable conditions seeds sown in the spring or early fall are capable of germinating and developing into seedlings in 8 to 12 days. Seeds are able to remain viable in the soil for up to 5 years.

Crested wheatgrass disperses its seed slowly throughout the year allowing some seed to escape peak periods of seed predation and increasing the number of seeds added to the seed bank. Tillers of crested wheatgrass usually stop growing by late-July in relation to soil drying. Increased precipitation in the fall (late August through October) stimulates growth of new shoots from stem bases. These new tillers overwinter in a 1-3 leaf state, and resume growth in the spring following snowmelt. Most of the shoots present in the spring are produced the previous fall.

Bluebunch wheatgrass also propagates by seed. Germination usually occurs in the fall, under a relatively large range of germination temperatures, and germination appears to be enhanced under alternating hot daytime and cool nighttime as opposed to constant temperatures. This is an advantage in a habitat where daytime and nighttime temperatures can vary widely such as in the sagebrush steppe. Seedling mortality, however, can be a problem. Over $90 \%$ of seedlings may perish in the first three years.

Bluebunch wheatgrass goes into summer dormancy as temperatures increase and moisture becomes limiting, although roots may grow into late August. With the onset of fall rains and low temperatures, bluebunch wheatgrass usually 
starts to regrow. A few weeks after fall rains, shoots begin to occur and will overwinter with 2 or 3 fully expanded foliage leaves. In contrast to crested wheatgrass, seed production is usually lower for bluebunch wheatgrass. Seeds are dispersed when mature, unlike crested wheatgrass which releases its seed over a longer period of time, perhaps reducing seedling establishment if seed predation is high or unfavorable growing conditions occur.

\section{Response to the Environment of the Intermountain West}

Research has shown major differences in how these two species respond to the environment of the Intermountain West. Crested wheatgrass appears to be able to extract more water from the soil during the course of a growing season than bluebunch wheatgrass. This may be due to a greater length of roots for the same amount of root weight in crested wheatgrass. More root surface area translates into a greater ability to uptake water and nutrients from the soil.

Differences in photosynthetic traits are also evident for both

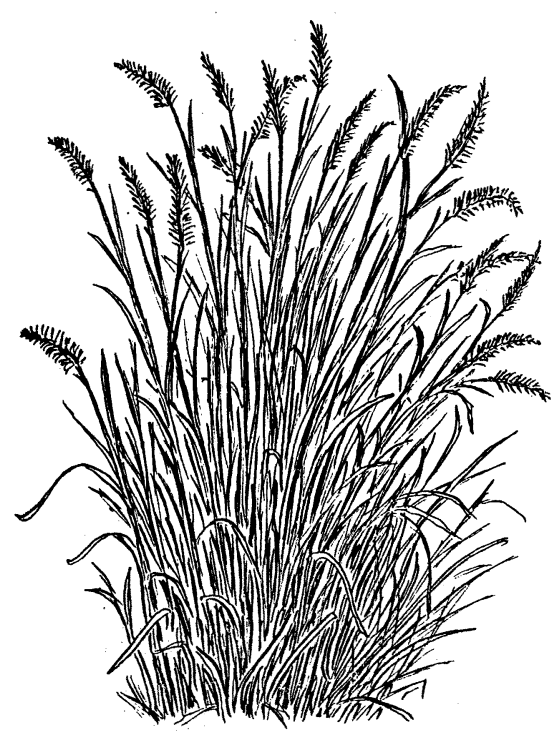

Crested wheatgrass species. When compared to bluebunch wheatgrass, crested wheatgrass has a lower investment of nitrogen and biomass per unit area of photosynthetic tissues. This trait partially explains why crested wheatgrass is able to tolerate herbivory to a greater degree than bluebunch wheatgrass does. Leaves and stems of crested wheatgrass are "cheaper" to make and less investment is lost when foliage is removed by grazing.

Another factor promoting post-grazing recovery in crested wheatgrass is the way in which this species reestablishes new leaves. It is important to note that maintenance of high photosynthetic rates is critical to the health and vigor of a plant, especially during the time of year when water and nutrients are plentiful. If a plant is grazed at this critical period, it must quickly reestablish leaves to maintain photosynthesis for production of subsequent roots, stems and leaves. Typically, carbohydrates for the reestablishment of leaves do not come from stored sources, but from remaining leaf area. The faster the tops are regrown, the quicker can carbohydrates be allocated to storage for future use.

In contrast, bluebunch wheatgrass is very slow to recover its top growth following heavy defoliation during the critical periods of late spring and early summer. Instead, this species allocates photosynthates to increased root production. The roots

\begin{tabular}{|c|c|}
\hline \multicolumn{2}{|c|}{ Common and scientific names of species } \\
\hline Common name & Scientific name \\
\hline Crested wheatgrass & $\begin{array}{l}\text { Agropyron desertorum (Fisch. ex Link) } \\
\text { Schult. }\end{array}$ \\
\hline Bluebunch wheatgrass & $\begin{array}{l}\text { Agropyron spicatum (Pursh) Scribn. and } \\
\text { Smith syn. Pseudoregneria spicata } \\
\text { (Pursh) } \\
\text { A. Love ssp. spicata }\end{array}$ \\
\hline Cheatgrass & Bromus tectorum $\mathrm{L}$ \\
\hline Medusahead & $\begin{array}{l}\text { Taeniatherum caput-medusae } \\
\text { (Sink. Meideris) }\end{array}$ \\
\hline
\end{tabular}

typically die off at the end of the growing season. A loss or lack of vigorous top growth coupled with photosynthates being used for roots that eventually die back, leads to a lower plant vigor if heavy grazing occurs for several years during the critical periods.

\section{Management Considerations}

Although crested wheatgrass and bluebunch wheatgrass are morphologically and phenologically similar, they have differences in their ability to tolerate grazing. Fundamental differences exist in their basic growth characteristics. Crested wheatgrass is able to tolerate severe defoliation better than bluebunch wheatgrass for a number of reasons. These include: 1) crested wheatgrass is able to absorb water and nutrients from the soil more efficiently;

2) crested wheatgrass is able to quickly reallocate photosynthates to shoots following grazing, and is able to produce more tillers and leaves per bunch than bluebunch wheatgrass;

3) crested wheatgrass has less costly investments of carbon and nitrogen in aboveground structures.

Peak production of crested wheatgrass tends to occur in April through June, and over 90 percent of total annual yield occurs before July. Crested wheatgrass starts growth early in the year and is best used as a spring pasture. It is recommended to wait until the leaves of crested wheatgrass are 4 inches high before grazing. Bluebunch wheatgrass begins growth later in the spring and is very susceptible to heavy grazing during its active growth phase.

Both crested and bluebunch wheatgrass can be incorporated into a grazing system. Crested wheatgrass is ideal for early spring grazing, while native pastures containing bluebunch wheatgrass respond better to deferred grazing later in the summer. Early spring grazing of bluebunch wheatgrass may also work if sufficient soil water is available to allow time for plants to establish regrowth and accumulate carbohydrate reserves before dormancy. Intensity and timing of grazing are a critical consideration to spring grazing. Late summer and fall grazing of bluebunch wheatgrass may be the most appropriate if cattle are removed early enough to allow for fall regrowth. Precipitation and fall temperatures are the limiting factors for fall regrowth of bluebunch wheatgrass. If grazed intensively during the growing season, bluebunch wheatgrass will probably need a period of rest during the subsequent year. Mowing 
and fall burning have been beneficial in removing old and dead plant material in crested wheatgrass. The removal of this older vegetation can increase the palatablility and grazing potential of both species.

\section{Additional Readings}

Bryant, L.D. 1993. Quality of bluebunch wheatgrass (Agropyron spicatum) as a winter range forage for Rocky Mountain elk (Cervus elaphus nelsoni) in the Blue Mountains of Oregon. Ph.D. Thesis. Oregon State University. 147pp.

Caldwell, M.M, J.H Richards, D.A. Johnson, R.S. Nowak, and R.S. Dzurec. 1981. Coping with herbivory: photosynthetic capacity and resource allocation in two semiarid Agropyron bunchgrasses. Oecologia 50:14-24.

Eissenstat, D.M. and M.M. Caldwell. 1988. Competitive ability is linked to rates of water extraction. A field study of two airdland tussock grasses. Oecologia 75:1-7.

Jackson, R.B. and M.M. Caldwell. 1989. The timing and degree of root proliferation in fertile-soil microsites for three cold-desert perennial. Oecologia 81:149-153.

Lodge, R.W., S. Smoliak, and A. Johnston. 1972. Managing crested wheatgrass pastures. Agriculture Canada. Publication 1473. Swift Current, Saskatchewan.

Miller, R.F., J.M. Seufert, and M.R. Haferkamp. 1986. The ecology and management of bluebunch wheatgrass (Agropyron spicatum): a review. Agricultural Experiment Station, Oregon State University, Corvallis, Ore. Station Bulletin 669, pp. 39.

Mueller, R.J. and J.H. Richards. 1986. Morphological analysis of tillering in Agropyron spicatum and Agropyron desertorum. Annals of Botany 58:911-912.

Nowak, R.S. and M.M. Caldwell. 1984. A test of compensatory photosynthesis in the field: implications for herbivory tolerance. Oecologia 61:311-318.

Olson, B.E. and J.H. Richards. 1988. Annual replacement of the tillers of Agropyron desertorum following grazing. Oecologia $76: 1-6$.
Parish, R., R. Coupe, and D. Lloyd. 1996. Plants of Southern Interior British Columbia. Lone Pine Publishing, Edmonton, AB. $463 \mathrm{pp}$.

Pyke, David. 1990. Comparative demography of co-occurring introduced and native tussock grasses: persistence and potential expansion. Oecologia 82:537-543.

Richards, J.H. 1984. Root growth response to defoliation in two Agropyron bunchgrasses: field observations with an improved root periscope. Oecologia 64:21-25.

Richards, J.H. and M.M. Caldwell. 1985. Soluble carbohydrates, concurrent photosynthesis and efficiency in regrowth following defoliation: a field study with Agropyron species. J. Appl. Econ. 22:907-920.

Rogler, G.A. and R.J. Lorenz. 1983. Crested wheatgrass-early history in the United States. J. Range. Manage. 36:91-93.

Sneva, F. and L. Rittenhouse. 1976. Crested wheatgrass production: Impacts on fertility, row spacing, and stand age. Oregon Agr. Exp. Sta. Tech. Bull. 135.

West, N. E., K.H. Rea, and R.O. Harniss. 1979. Plant demographic studies in southern Idaho. Ecology 60:376-388.

Young, J.A., R.E. Eckert, Jr., and R.A. Evans. 1981. Temperature profiles for germination of bluebunch and beardless wheatgrasses. J. Range Manage. 34(2):84-89.

At the time of submission, authors were Water Quality Technician, Agricultural and Agri-Foods Canada, Kamloops Range Research Unit, Kamloops, B.C. V2B 8A9, and Graduate Research Assistant and Professor, Department of Rangeland Resources, Oregon State University, Corvallis, Oregon, USA 97331. Manuscript is submitted as Technical Paper \#11658 Oregon Agricultural Experiment Station, Oregon State University, Corvallis, Oregon, USA 97331. Thanks to William Krueger and Michael Borman for their helpful comments on earlier drafts of this paper. 